\title{
SALINITY TOLERANCE CLASSIFICATION OF SUNFLOWER (Helianthus annuus L.) AND SAFFLOWER (Carthamus tinctorius L.) BY CLUSTER AND PRINCIPAL COMPONENT ANALYSIS
}

\author{
KAYA, M. D..$^{1 *}$ - AKDOĞAN, G. ${ }^{2}-$ KULAN, E. G. ${ }^{1}-$ DAĞHAN, H. ${ }^{3}-$ SARI, A. ${ }^{1}$ \\ ${ }^{I}$ Department of Field Crops, Faculty of Agriculture, Eskişehir Osmangazi University \\ Eskişehir, Turkey \\ ${ }^{2}$ Department of Field Crops, Faculty of Agriculture, Ankara University \\ Ankara, Turkey \\ ${ }^{3}$ Department of Soil Science and Plant Nutrition, Faculty of Agriculture, Eskişehir Osmangazi \\ University, Eskişehir, Turkey \\ *Corresponding author \\ e-mail:demirkaya76@hotmail.com \\ (Received $16^{\text {th }}$ Jan 2019; accepted $20^{\text {th }}$ Feb 2019)
}

\begin{abstract}
Germination, emergence and seedling growth are considerably restricted by salinity. The study aimed to compare safflower with sunflower during germination and seedling growth for tolerance to salinity. Four safflower cultivars (Asol, Balc1, Linas and Olas) and sunflower hybrids (Esbella, Oliva, Cartago and C-180) were subjected to various $\mathrm{NaCl}$ levels (control, 5, 10 and $15 \mathrm{dS} \mathrm{m}^{-1}$ ) and their seedling growth and ion concentration were investigated. Classification for salinity tolerance was performed by a combination of Principal Component (PCA) and Cluster Analysis considering germination percentage (GP), mean germination time (MGT), vigor index (VI), $\mathrm{Na}^{+}$and $\mathrm{Na}: \mathrm{K}$ ratio in seedlings. The results elicited that genotypes exhibited varying responses to salinity, MGT significantly prolonged and a dramatic reduction in seedling growth of sunflower was observed. The highest seedling fresh weight was observed in Esbella among sunflower and Asol among safflower and, $\mathrm{Na}^{+}$ concentration of seedlings increased with increasing salinity levels. The safflower seedlings absorbed a higher $\mathrm{Na}^{+}$ than that of sunflower. Safflower cv. Balc1 had the highest $\mathrm{Na}^{+}$concentration in seedling and it maintains its ion balance (Na:K ratio) at all levels of $\mathrm{NaCl}$. Cluster analysis revealed that there were two groups for salinity tolerance, and the safflower cultivars were apparently more salt-tolerant than sunflower hybrids.
\end{abstract}

Keywords: Carthamus tinctorius, Heliathus annuus, $\mathrm{NaCl}$, resistance, ion balance

\section{Introduction}

Sunflower (Helianthus annuus L.) and safflower (Carthamus tinctorius L.) are the most important oil seed crops from Asteraceae family. These plants are usually preferred in arid and semi-arid regions under rain-fed conditions, where low rainfall and high evapotranspiration during vegetation periods restricts the growth of crop plants (Kaya et al., 2003). Under these conditions, drought and salinity are the major abiotic stresses that severely inhibit germination, seedling establishment and plant growth; consequently, seed yield decreases (Hussain et al., 2016). The restrictive effects of salinity on plant life are mainly osmotic effect of salts and toxic effects of $\mathrm{Na}^{+}, \mathrm{Cl}^{-}$and $\mathrm{SO}_{4}{ }^{-2}$ ions (Ashraf and Fatima, 1994; Chinnusamy et al., 2005; Muhammad and Hussain, 2010), but some crop plants or varieties in a species have been more tolerant than the others.

Sunflower and safflower are classified as moderately salt tolerant based on seed yield (Grieve et al., 2012). When the plants were to be classified according to salinity tolerance, they were compared under saline and non-saline conditions with each other in terms of plant growth parameters, yield and quality performance. For the classification, the controlled 
conditions are commonly preferred because the environmental changes are discarded. A lot of researches on the comparison of genotypes, varieties or species for tolerance to salt stress have been conducted and tried to find a valid selection criteria for the tolerance mechanism (Hussain et al., 2016). Plant biomass and photosynthetic activity by Munns and Tester (2008), Siddiqi et al. (2009) and Farooq et al. (2015), reduced chlorophyll content by Ashraf (2004), leaf water and osmotic potential by Gadallah (1996) and Munns (2002), ion toxicity by Munns et al. (2006) and Rejili et al. (2007) and reduction in seed yield by Francois (1996) and Natarajan et al. (2005) have been considered the suitable parameters for ranking the genotypes for salinity tolerance. On the other hand, these parameters to be used for selection criteria have not been easily investigated and heritable. Recently, several indices have been commonly developed for grouping plants under salt stresses (Nikbakht et al., 2010; Zafar et al., 2015; Krishnamurthy et al., 2016). Saboora and Kiarostami (2006) and Kaya et al. (2012) classified the genotypes using all the parameters they measured by using a combination of Cluster and Principal component analysis (PCA) instead of searching a parameter, and lastly Aslam et al. (2017) ranked lentil germplasm for salinity tolerance using multiple traits by PCA based Biplot. Multivariate analysis has the superiority for genotypic classification because accuracy is considerably increased using multiple traits, and gives a general tolerance level based over mean values derived from each stress level (Zeng et al., 2002). For these reasons, this research focused on determining more tolerant plant to salinity between sunflower and safflower considering germination and seedling growth traits, sodium concentration and sodium / potassium ratio in seedling.

\section{Materials and Methods}

This study was conducted at Seed Science Laboratory of Department of Field Crops, Eskişehir Osmangazi University, Turkey. Four native safflower cultivars Asol, Balcı, Linas and Olas registered in Turkey, and four sunflower hybrids Esbella, Oliva, Cartago and Pioneer C-180 were used in the study. The seeds of the respective varieties were subjected to three levels of the electrical conductivity of 5,10 and $15 \mathrm{dS} \mathrm{m}^{-1}$ constituted by $\mathrm{NaCl}$ along with distilled water as a control treatment.

Two hundred $(4 \times 50)$ seeds of each genotype were inserted into three layer filter papers irrigated with $7 \mathrm{~mL}$ of the saline solutions for each paper. After filter papers with seeds were rolled, they were replaced into a sealed plastic bag to prevent moisture evaporation. Each rolled paper was renewed every 2 days after incubation to avoid the salt accumulation. Germination tests were conducted at $25 \pm 1{ }^{\circ} \mathrm{C}$ in the dark condition and a seed with $2 \mathrm{~mm}$ radicle was counted every $24 \mathrm{~h}$ for $10 \mathrm{~d}$ as germinated. The speed of germination was evaluated by means of mean germination time (MGT) which was represented by the ISTA (2003) rules. MGT $=\Sigma(\mathrm{Dn}) / \Sigma \mathrm{n}$, where, $\mathrm{n}$ is the seed number germinated on day $\mathrm{D}$, and $\mathrm{D}$ is the number of days from the beginning of germination test. Ten seedlings selected from each treatment at the $10^{\text {th }}$ day were sampled for determination of seedling growth traits such as root length (RL), shoot length (SL) and seedling fresh weight (SFW). Vigor index (VI) is calculated by multiplying germination percentage (GP) $(\%)$ and seedling length $(\mathrm{cm})$ and the genotypes with the higher vigor index are considered to be more vigorous (Abdul-Baki and Anderson, 1973). Also, percent reduction in shoot length and seedling fresh weight between control and $15 \mathrm{dS} \mathrm{m}^{-1}$ were calculated as (control plants-stressed plants / control plants) $\times 100$ described by Shirani Rad and Abbasian (2011). The index didn't give in Tables because they used only for statistical evaluation. To determine $\mathrm{Na}^{+}$and $\mathrm{K}^{+}$concentration in seedlings, all the seedlings from each treatment were used. After the seedlings were firstly washed with 
distilled water three times, excessive water on seedling surface water was dried with paper towel. The weighed seedlings were dried in an oven at $70^{\circ} \mathrm{C}$ for 48 hours and then they were grounded. Plant samples were acid digested in microwave oven, and $\mathrm{Na}^{+}$and $\mathrm{K}^{+}$ concentrations were measured using a flame photometric method described by Kacar and Inal (2008).

The experiment was established as two-factor factorial (salinity $\times$ genotype) arranged in a completely randomized design (CRD) with 4 replications. Data were statistically analyzed by MSTAT-C program (Michigan State University). The differences between the means were tested by the Least Significant Differences at $\mathrm{P}<0.05$ level. For ranking the varieties for salinity tolerance, Principle Component (PCA) and Cluster Analysis were done by SPSS.

\section{Results and Discussion}

A two-way interaction was significant for all characters of safflower varieties $(\mathrm{P}<0.05$; Table 1). Similar germination percentages from safflower cultivars were observed while Balc1 gave the highest germination percentage at all levels of $\mathrm{NaCl}$. MGT was clearly prolonged by increasing $\mathrm{NaCl}$ levels, and $\mathrm{NaCl}$ level of $15 \mathrm{dS} \mathrm{m}^{-1}$ led to retardation in germination more dramatically compared to lower levels of $\mathrm{NaCl}$. The most rapid time to germination at $15 \mathrm{dS}$ $\mathrm{m}^{-1}$ was calculated in Linas (1.96 days). Compared to control, the root length was remarkably depressed at $15 \mathrm{dS} \mathrm{m}^{-1}$ and Balc1 gave the longest root under $\mathrm{NaCl}$ stresses. The shoot length of safflower was the most sensitive parameter adversely affected by salinity. It was drastically diminished and the longest shoot at $15 \mathrm{dS} \mathrm{m}^{-1}$ was measured in Asol with $7.00 \mathrm{~cm}$. Similarly, the seedling fresh weight was reduced under salt stresses and Asol exhibited a heavier seedling than the others did. In terms of seedling growth and germination percentage together under salinity, the highest vigor index was obtained from Balcı under all levels of $\mathrm{NaCl}$.

Table 1. Germination and seedling growth of safflower cultivars affected by $\mathrm{NaCl}$ levels

\begin{tabular}{|c|c|c|c|c|c|c|c|}
\hline 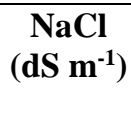 & Cultivars & $\begin{array}{c}\text { GP } \\
\%\end{array}$ & $\begin{array}{c}\text { MGT } \\
\text { day }\end{array}$ & $\begin{array}{l}\text { RL } \\
\text { cm }\end{array}$ & $\begin{array}{l}\mathrm{SL} \\
\mathrm{cm}\end{array}$ & $\begin{array}{c}\text { SFW } \\
\text { mg } \\
\text { plant }^{-1}\end{array}$ & VI \\
\hline \multirow[t]{4}{*}{ Control } & Asol & $92.0^{\text {cde }}$ & $1.25^{\mathrm{g}}$ & $4.55^{\mathrm{e}}$ & $7.68^{b}$ & $4.59^{\mathrm{a}}$ & $1063^{\mathrm{d}-\mathrm{g} *}$ \\
\hline & Balc1 & $95.0^{\mathrm{abc}}$ & $1.87^{\mathrm{c}}$ & $8.38^{\mathrm{ab}}$ & $7.05^{\mathrm{bc}}$ & $3.37^{\mathrm{c}}$ & $1466^{\mathrm{b}}$ \\
\hline & Linas & $94.5^{\mathrm{bcd}}$ & $1.42^{\mathrm{ef}}$ & $6.20^{\mathrm{d}}$ & $4.35^{\mathrm{g}}$ & $2.64^{\mathrm{d}}$ & $1003^{\text {efg }}$ \\
\hline & Olas & $98.0^{\mathrm{ab}}$ & $1.06^{\mathrm{i}}$ & $6.60^{\mathrm{cd}}$ & $3.10^{\mathrm{i}}$ & $2.08^{f}$ & $951^{\mathrm{fg}}$ \\
\hline \multirow[t]{4}{*}{5} & Asol & $97.0^{\mathrm{abc}}$ & $1.11^{\mathrm{hi}}$ & $4.50^{\mathrm{e}}$ & $7.00^{\mathrm{bc}}$ & $4.39^{a}$ & $1116^{\mathrm{d}-\mathrm{f}}$ \\
\hline & Balc1 & $100.0^{\mathrm{a}}$ & $1.67^{\mathrm{d}}$ & $9.38^{\mathrm{a}}$ & $8.83^{\mathrm{a}}$ & $3.26^{\mathrm{c}}$ & $1821^{\mathrm{a}}$ \\
\hline & Linas & $97.5^{\mathrm{ab}}$ & $1.09^{\mathrm{i}}$ & $8.78^{\mathrm{a}}$ & $6.80^{\mathrm{cd}}$ & $2.51^{\mathrm{de}}$ & $1519^{\mathrm{b}}$ \\
\hline & Olas & $98.5^{\mathrm{ab}}$ & $1.38^{\mathrm{f}}$ & $8.78^{\mathrm{a}}$ & $3.88^{\mathrm{gh}}$ & $2.05^{\mathrm{fg}}$ & $1247^{\mathrm{cd}}$ \\
\hline \multirow[t]{4}{*}{10} & Asol & $98.0^{\mathrm{ab}}$ & $1.10^{\mathrm{i}}$ & $4.50^{\mathrm{e}}$ & $6.88^{\mathrm{cd}}$ & $3.78^{b}$ & $1115^{\text {def }}$ \\
\hline & Balc1 & $99.0^{\mathrm{ab}}$ & $1.75^{\mathrm{d}}$ & $8.40^{\mathrm{ab}}$ & $7.18^{\mathrm{bc}}$ & $3.33^{\mathrm{c}}$ & $1542^{\mathrm{b}}$ \\
\hline & Linas & $98.5^{\mathrm{ab}}$ & $1.20^{\mathrm{gh}}$ & $6.63^{\mathrm{cd}}$ & $5.45^{\mathrm{f}}$ & $2.11^{\mathrm{f}}$ & $1189^{d}$ \\
\hline & Olas & $98.5^{\mathrm{ab}}$ & $1.49^{\mathrm{e}}$ & $6.30^{\mathrm{d}}$ & $3.70^{\text {ghi }}$ & $1.87^{\mathrm{fg}}$ & $985^{\mathrm{fg}}$ \\
\hline \multirow[t]{4}{*}{15} & Asol & $98.5^{\mathrm{ab}}$ & $1.96^{\mathrm{bc}}$ & $4.78^{\mathrm{e}}$ & $7.00^{\mathrm{bc}}$ & $3.49^{\mathrm{bc}}$ & $1160^{\mathrm{de}}$ \\
\hline & Balc1 & $98.5^{\mathrm{ab}}$ & $1.98^{\mathrm{b}}$ & $7.58^{\mathrm{bc}}$ & $6.20^{\mathrm{de}}$ & $3.24^{\mathrm{c}}$ & $1357^{\mathrm{bc}}$ \\
\hline & Linas & $97.0^{\mathrm{abc}}$ & $2.13^{\mathrm{a}}$ & $6.93^{\mathrm{cd}}$ & $5.55^{\mathrm{ef}}$ & $2.15^{\mathrm{ef}}$ & $1211^{\mathrm{cd}}$ \\
\hline & Olas & $89.5^{\mathrm{de}}$ & $2.09^{\mathrm{a}}$ & $5.95^{\mathrm{d}}$ & $3.20^{\mathrm{hi}}$ & $1.68^{\mathrm{g}}$ & $819^{g}$ \\
\hline
\end{tabular}

*: Means followed by the same letter(s) are not significantly different at $\mathrm{p}<0.05$. GP: germination percentage, MGT: mean germination time, RL: root length, SL: shoot length, SFW: seedling fresh weight, VI: vigor index 
The responses of the investigated sunflower hybrids to salinity stresses are illustrated in Table 2. A significant difference was determined for germination percentage of sunflower as affected by the interaction of hybrids $\times \mathrm{NaCl}$ levels. In general, sunflower hybrids gave similar germination percentage under $\mathrm{NaCl}$ levels, but lower germination percentage was observed in C-108 and Cartego at $5 \mathrm{dS} \mathrm{m} \mathrm{m}^{-1}$. MGTs of sunflower hybrids also showed similarity to each other while it was prominently extended by an increase in $\mathrm{NaCl}$ level. Also, an apparent reduction in root length was detected by increasing salinity; however, the root growth of Esbella was not adversely influenced. Esbella and Oliva gave the highest root and shoot length under $\mathrm{NaCl}$ stresses. Seedling fresh weight of sunflower hybrids was gradually declined depending on changes in root and shoot growth, but Esbella showed the superiority to other hybrids for seedling growth under salinity. The highest vigor

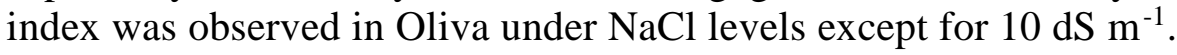

Table 2. Germination and seedling growth of sunflower hybrids affected by NaCl levels

\begin{tabular}{|c|c|c|c|c|c|c|c|}
\hline $\begin{array}{c}\mathrm{NaCl} \\
\left(\mathrm{dS} \mathrm{m}^{-1}\right)\end{array}$ & Hybrids & $\begin{array}{c}\text { GP } \\
\%\end{array}$ & $\begin{array}{c}\text { MGT } \\
\text { day }\end{array}$ & $\begin{array}{l}\mathrm{RL} \\
\mathrm{cm}\end{array}$ & $\begin{array}{l}\text { SL } \\
\mathrm{cm}\end{array}$ & $\begin{array}{c}\text { SFW } \\
\text { mg } \\
\text { plant }^{-1}\end{array}$ & VI \\
\hline \multirow[t]{4}{*}{ Control } & Esbella & $89.0^{\text {cde }}$ & $2.67^{\text {bcd }}$ & $7.88^{\mathrm{d}}$ & $10.43^{b c}$ & $7.72^{\mathrm{a}}$ & $1628^{\mathrm{bcd} *}$ \\
\hline & Oliva & $94.0^{\mathrm{abc}}$ & $2.77^{\mathrm{bc}}$ & $12.52^{\mathrm{a}}$ & $12.70^{\mathrm{a}}$ & $5.53^{\mathrm{cd}}$ & $2369^{a}$ \\
\hline & C-108 & $85.5^{\text {def }}$ & $2.90^{\mathrm{b}}$ & $10.65^{b}$ & $6.55^{\mathrm{ef}}$ & $3.45^{\mathrm{fg}}$ & $1471^{\text {cde }}$ \\
\hline & Cartego & $93.0^{\mathrm{a}-\mathrm{d}}$ & $2.83^{\mathrm{b}}$ & $9.73^{c}$ & $3.20^{\mathrm{gh}}$ & $2.49^{\mathrm{h}-\mathrm{k}}$ & $1202^{\text {ef }}$ \\
\hline \multirow[t]{4}{*}{5} & Esbella & $90.0^{\mathrm{b}-\mathrm{e}}$ & $3.02^{\mathrm{a}}$ & $7.98^{\mathrm{d}}$ & $9.83^{\mathrm{bc}}$ & $7.50^{\mathrm{a}}$ & $1599^{\mathrm{bcd}}$ \\
\hline & Oliva & $92.0^{\mathrm{a}-\mathrm{e}}$ & $2.80^{\mathrm{bc}}$ & $8.55^{\mathrm{d}}$ & $11.40^{\mathrm{ab}}$ & $4.68^{\mathrm{de}}$ & $1877^{\mathrm{b}}$ \\
\hline & C-108 & $78.0^{\mathrm{fg}}$ & $2.69^{\mathrm{bcd}}$ & $6.50^{\mathrm{e}}$ & $5.88^{\mathrm{f}}$ & $3.28^{\mathrm{fgh}}$ & $1008^{f}$ \\
\hline & Cartego & $71.0^{\mathrm{g}}$ & $2.77^{\mathrm{bc}}$ & $7.88^{\mathrm{d}}$ & $2.50^{\mathrm{h}}$ & $2.27^{\mathrm{ijk}}$ & $712^{\text {gh }}$ \\
\hline \multirow[t]{4}{*}{10} & Esbella & $98.0^{\mathrm{ab}}$ & $2.33^{\mathrm{e}}$ & $8.63^{\mathrm{d}}$ & $10.43^{b c}$ & $6.51^{\mathrm{b}}$ & $1867^{b}$ \\
\hline & Oliva & $100.0^{\mathrm{a}}$ & $2.29^{\mathrm{e}}$ & $5.40^{\mathrm{f}}$ & $11.40^{\mathrm{ab}}$ & $3.99^{\mathrm{ef}}$ & $1705^{\mathrm{bc}}$ \\
\hline & C-108 & $100.0^{\mathrm{a}}$ & $2.30^{\mathrm{e}}$ & $4.53^{\mathrm{g}}$ & $8.00^{\mathrm{de}}$ & $2.86^{\text {ghi }}$ & $1203^{\text {ef }}$ \\
\hline & Cartego & $96.0^{\mathrm{abc}}$ & $2.71^{\mathrm{bc}}$ & $1.68^{1}$ & $3.75^{\mathrm{gh}}$ & $1.79^{\mathrm{jk}}$ & $521^{\mathrm{h}}$ \\
\hline \multirow[t]{4}{*}{15} & Esbella & $84.0^{\mathrm{ef}}$ & $2.94^{\mathrm{b}}$ & $8.53^{\mathrm{d}}$ & $8.90^{\mathrm{cd}}$ & $6.28^{b c}$ & $1397^{\mathrm{de}}$ \\
\hline & Oliva & $95.0^{\mathrm{abc}}$ & $2.39^{\mathrm{de}}$ & $4.85^{\mathrm{fg}}$ & $9.93^{\mathrm{bc}}$ & $3.05^{\mathrm{ghi}}$ & $1431^{\text {cde }}$ \\
\hline & C-108 & $89.0^{\text {cde }}$ & $2.51^{\text {cde }}$ & $3.30^{\mathrm{h}}$ & $6.88^{e f}$ & $2.62^{\mathrm{g}-\mathrm{j}}$ & $928^{c}$ \\
\hline & Cartego & $93.5^{\mathrm{a}-\mathrm{d}}$ & $2.78^{\mathrm{bc}}$ & $2.33^{\mathrm{i}}$ & $4.28^{\mathrm{g}}$ & $1.70^{\mathrm{k}}$ & $619^{d}$ \\
\hline
\end{tabular}

*: Means followed by the same letter(s) are not significantly different at $\mathrm{p}<0.05$. GP: germination percentage, MGT: mean germination time, RL: root length, SL: shoot length, SFW: seedling fresh weight, VI: vigor index

Seedling of safflower cultivars accumulated much more $\mathrm{Na}^{+}$than did the sunflower hybrids, and the amount of $\mathrm{Na}^{+}$was the highest in Balc1 at all levels of $\mathrm{NaCl}$ (Figure 1). Moreover, $\mathrm{NaCl}$ level of $15 \mathrm{dS} \mathrm{m}{ }^{-1}$, Asol seedlings absorbed more $\mathrm{Na}^{+}$from the medium. Na:K ratio represented that Balc1 maintained the ionic balance under salt stresses while Asol become unbalanced at $15 \mathrm{dS} \mathrm{m}^{-1}$ (Figure 2).

PCA and Cluster Analysis performed by mean values of germination percentage, MGT, vigor index, percent reduction in seedling length and fresh weight, ion concentration in seedlings and $\mathrm{Na}: \mathrm{K}$ ratio emerged that two main groups were constituted (Figure 3). The safflower varieties were found more tolerant than sunflower varieties to $\mathrm{NaCl}$ stresses. Among safflower varieties, the superiority of Balc1 and Asol appeared under $\mathrm{NaCl}$ stresses. 


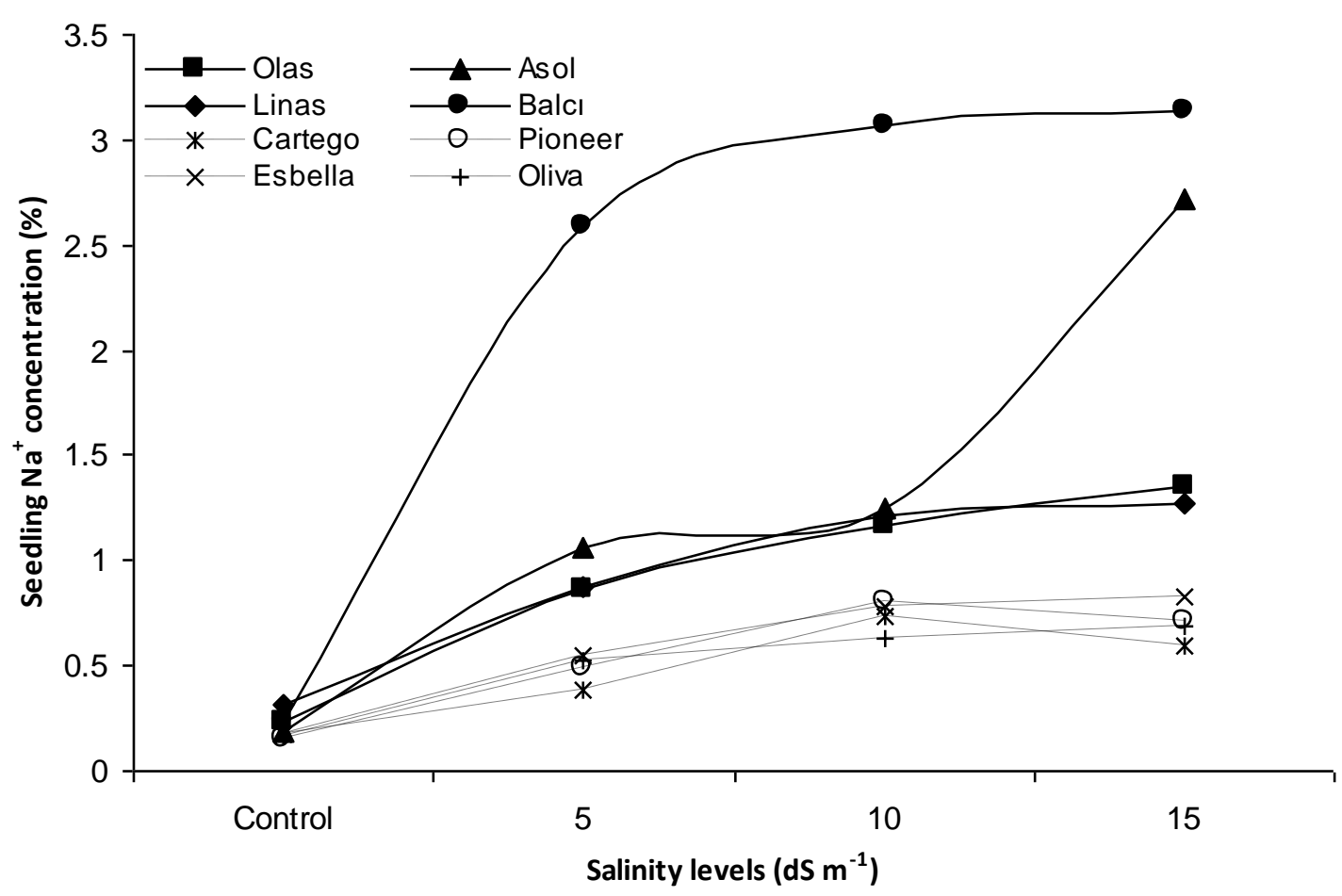

Figure 1. Seedling $\mathrm{Na}^{+}$concentration of safflower and sunflower genotypes subjected to various levels of $\mathrm{NaCl}$

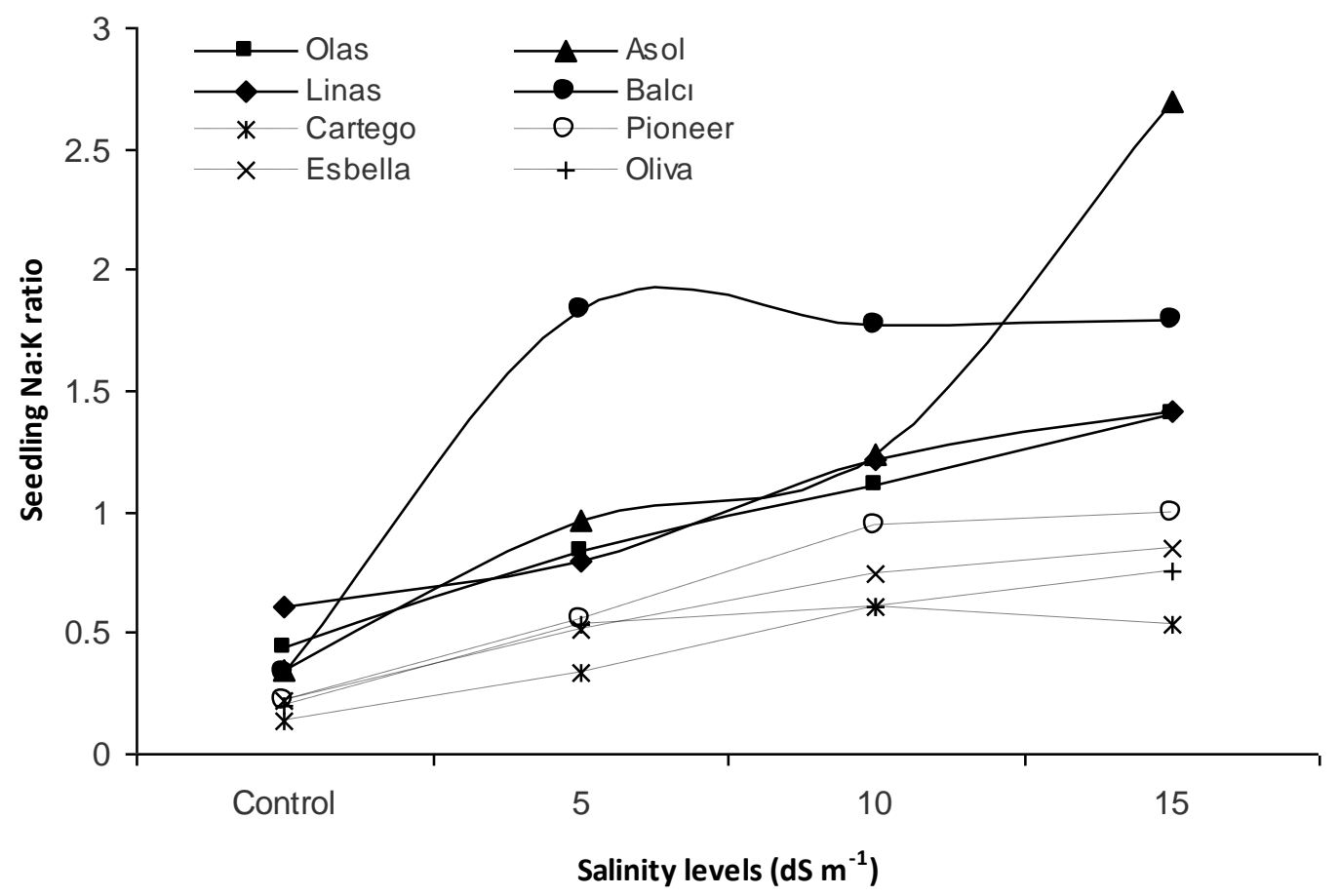

Figure 2. Seedling Na:K ratio of safflower and sunflower genotypes subjected to various levels of $\mathrm{NaCl}$ 


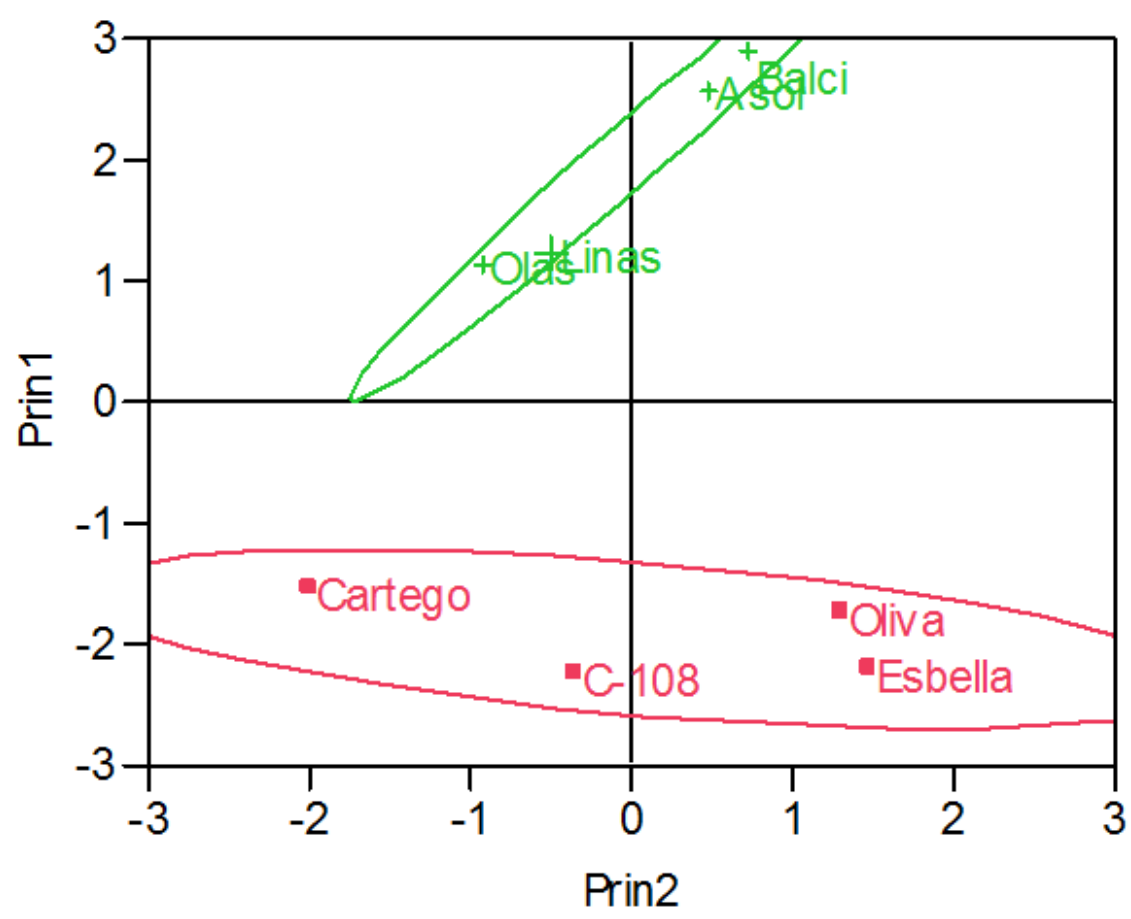

Figure 3. Classification of sunflower and safflower genotypes for salinity tolerance using germination percentage, $\mathrm{MGT}$, vigor index, $\mathrm{Na}^{+}$and $\mathrm{K}^{+}$concentrations of seedling, $\mathrm{Na}: \mathrm{K}$ ratio, percent reduction in seedling length and fresh weight measured at $10 \mathrm{~d}$ old seedlings

Salt concentration between control and $15 \mathrm{dS} \mathrm{m}{ }^{-1}$ didn't lead to a clear increase or decrease in germination percentage of safflower and sunflower genotypes while the statistical differences were determined. Similar findings were reported by Kaya et al. (2006) who found no significant changes in germination with increasing salinity stresses in sunflower. Genotypic variation at $15 \mathrm{dS} \mathrm{m} \mathrm{m}^{-1}$ was significantly appeared and the most rapid germination was recorded in Asol and Oliva. Generally, $\mathrm{NaCl}$ levels slightly affected germination of both species, indicating that it should not be used for selection criteria for salinity tolerance. The findings are confirmed by the results of Muhammad and Hussain (2010), who reported that $\mathrm{NaCl}$ levels up to $15 \mathrm{dS} \mathrm{m} \mathrm{m}^{-1}$ didn't severely influence germination in flax. Salts constitute osmotic stress or specific ion toxicity, especially $\mathrm{Na}$, responsible for retarding and inhibiting germination of several plants as declared by Chinnusamy et al. (2005), Okcu et al. (2005) in pea, and Atak et al. (2006) in triticale. Nevertheless, seedling growth of both species was severely depressed while sunflower seedling was more sensitive to increasing salinity. The greatest reduction was observed in shoot length of sunflower compared to safflower. Depending on root and shoot growth depletion, seedling fresh weight was severely reduced and this reduction was obvious at $15 \mathrm{dS} \mathrm{m}$. These findings have supported the results of previous researches in sunflower by Ashraf and O'Leary (1997), Mohammed et al. (2002), Kaya et al. (2006), Day et al. (2008) and in safflower by Kaya et al. (2003), Siddiqi et al. (2007) and Farhoudi and Motamedi (2010).

Seedling of safflower cultivars accumulated much more $\mathrm{Na}^{+}$than did the sunflower hybrids, and the amount of $\mathrm{Na}^{+}$was the highest in Balc1 at all levels of $\mathrm{NaCl}$ (Figure 1). 
Moreover, $\mathrm{Na}^{+}$concentration in Asol seedlings clearly improved at $15 \mathrm{dS} \mathrm{m}^{-1}$. This means that Balc1 could keep up with higher $\mathrm{Na}^{+}$concentration in cells without any significant depression or vitality in seedlings (Chinnusamy et al., 2005). Conversely, $\mathrm{NaCl}$ depressed the seedling growth of sunflower hybrids, although they absorbed less $\mathrm{Na}^{+}$from the germination medium. It seems that $\mathrm{K}^{+}$in the seeds was leaked into the medium and the seedling uptook $\mathrm{Na}^{+}$from the medium. Chinnusamy et al. (2005) and Hussain et al. (2016) represented that increasing $\mathrm{NaCl}$ levels caused an increase in $\mathrm{K}^{+}$ leakage from seeds. Atak et al. (2006) found $\mathrm{Na}^{+}$concentration in seeds was increased by increasing $\mathrm{NaCl}$ levels regardless of $\mathrm{K}^{+}$level. In terms of ion balance, $\mathrm{Na}: \mathrm{K}$ ratio, Balcı was the most stable genotype against increasing $\mathrm{NaCl}$ levels, although Asol showed an extraordinary behavior at $15 \mathrm{dS} \mathrm{m}^{-1}$ (Figure 2). It is argued that Asol could not maintain the ion balance and ultimately $\mathrm{Na}^{+}$was surprisingly peaked at $15 \mathrm{dS} \mathrm{m}^{-1}$.

Principle component analysis (PCA) has been effectively implemented with sorting the genotypes under different environmental conditions, especially drought and salinity stresses (Kaya et al., 2012; Aslam et al., 2017). Cluster analysis and PCA analysis were made on mean data obtained from each genotype subjected to various salinity stresses. Our results showed that two main groups were discovered by Cluster analysis, and PCA1 (67.2\%) and PCA2 (13.8\%) represented $81.0 \%$ of data variability. It is strongly declared that safflower varieties were more tolerant to salinity than sunflower hybrids along with differences among genotypes.

\section{Conclusion}

This experimental preliminary study shows that significant differences between safflower and sunflower for salinity tolerance apparently existed at germination and early seedling growth. The superiority of safflower under saline condition was clearly identified, while there were genotypic variations within the species; eliciting that Balc1 and Asol among safflower, Oliva and Esbella among sunflower were more tolerant to $\mathrm{NaCl}$ stresses. However, the further study is required to evaluate salt tolerance subsequent growth stages of safflower and sunflower under field conditions to confirm their tolerance levels.

\section{REFERENCES}

[1] Abdul-Baki, A. A., Anderson, J. D. (1973): Vigor determination in soybean seed by multiple criteria. - Crop Science 13: 630-633.

[2] Ashraf, M. (2004): Some important physiological selection criteria for salt tolerance in plants. - Flora 199: 361-376.

[3] Ashraf, M., Fatima, H. (1994): Intra-specific variation for salt tolerance in linseed (Linum usitatissimum L.). - Journal of Agronomy and Crop Science 173: 193-203.

[4] Ashraf, M., O'Leary, J. W. (1997): Responses of a salt tolerant and a salt-sensitive line of sunflower varying sodium/calcium ratios in saline sand culture. - Journal of Plant Nutrition 20: 361-377.

[5] Aslam, M., Maqbool, M. A., Zaman, Q. U., Shahid, M., Akhtar, M. A., Rana, A. S. (2017): Comparison of different tolerance indices and PCA Biplot analysis for assessment of salinity tolerance in lentil (Lens culinaris) genotypes. - International Journal of Agriculture and Biology 19: 470-478. 
[6] Atak, M., Kaya, M. D., Kaya, G., C1k111, Y., Ciftci, C. Y. (2006): Effects of NaCl on the germination, seedling growth and water uptake of triticale. - Turkish Journal of Agriculture and Forestry 30: 39-47.

[7] Chinnusamy, V., Jagendorf, A., Zhu, J. K. (2005): Understanding and improving salt tolerance in plants. - Crop Science 45: 437-448.

[8] Muhammad, Z., Hussain, F. (2010): Effect of $\mathrm{NaCl}$ salinity on the germination and seedling growth of some medicinal plants. - Pakistan Journal of Botany 42: 889-897.

[9] Day, S., Kaya, M. D., Kolsarıc1, Ö. (2008): Effects of $\mathrm{NaCl}$ levels on germination of some confectionary sunflower (Helianthus annuus L.) genotypes. - Journal of Agricultural Sciences 14: 230-236.

[10] Farhoudi, R., Motamedi, M. (2010): Effect of salt stress and seed size on germination and early seedling growth of safflower (Carthamus tinctorius L.). - Seed Science and Technology 38: 73-78.

[11] Farooq, M., Hussain, M., Wakeel, A., Siddique, K. H. M. (2015): Salt stress in maize: effects, resistance mechanism and management. A review. - Agronomy for Sustainable Development 35: 461-48.

[12] Francois, L. E. (1996): Salinity effects on four sunflower hybrids. - Agronomy Journal 88: 215-219.

[13] Gadallah, M. A. A. (1996): Abscisic acid, temperature and salinity interactions on growth and some mineral elements in Carthamus plants. - Plant Growth Regulation 20: 225-236.

[14] Grieve, C. M., Grattan, S. R., Mass, E. V. (2012): Plant salt tolerance. - In: W.W. Wallender and K.K. Tanji (ed.). ASCE Manual and Reports on Engineering Practice No. 71 Agricultural Salinity Assessment and Management ( $2^{\text {nd }}$ Edition). ASCE, Reston, VA. Chapter 13: 405-459.

[15] Hussain, M. I., Lyra, D. A., Farooq, M., Nikoloudakis, N., Khalid, N. (2016): Salt and drought stresses in safflower: A review. - Agronomy for Sustainable Development 36: 4.

[16] ISTA, (2003): International Rules for Seed Testing. - International Seed Testing Association, Switzerland.

[17] Kacar, B., Inal, A. (2008): Plant Analysis. - Nobel Press, Ankara.

[18] Kaya, M. D., İpek, A., Öztürk, A. (2003): Effects of different soil salinity levels on germination and seedling growth of safflower (Carthamus tinctorius L.). - Turkish Journal of Agriculture and Forestry 27: 221-227.

[19] Kaya, M. D., Okçu, G., Atak, M., Çıkı1ı, Y., Kolsarıcı, Ö. (2006): Seed treatments to overcome salt and drought stress during germination in sunflower (Helianthus annuus L.). - European Journal of Agronomy 24: 291-295.

[20] Kaya, M. D., Day, S., Cikili, Y., Arslan, N. (2012): Classification of some linseed (Linum usitatissimum L.) genotypes for salinity tolerance using germination, seedling growth, and ion content. - Chilean Journal of Agricultural Research 72: 27-32.

[21] Krishnamurthy, S. L., Sharma, P. C., Sharma, S. K., Batra, V., Kumar, V., Rao, L. V. S. (2016): Effects of salinity and use of stress indices of morphological and physiological traits at the seedling stage in rice. - Indian Journal of Experimental Biology 54: 843-850.

[22] Mohammed, E. M., Benbella, M., Talouizete, A. (2002): Effect of sodium chloride on sunflower (Helianthus annuus L.) seed germination. - Helia 25: 51-58.

[23] Munns, R. (2002): Comparative physiology of salt and water stress. - Plant Cell Environment 25: 239-250.

[24] Munns, R., Tester, M. (2008): Mechanism of salinity tolerance. - Annual Review of Plant Biology 59: 651-681.

[25] Natarajan, S. K., Ganapathy, M., Krishnakumar, S., Dhanalakshmi, R., Saliha, B. B. (2005): Grouping of rice genotypes for salinity tolerance based upon grain yield and $\mathrm{Na}: \mathrm{K}$ ratio under coastal environment. - Research Journal of Agriculture and Biological Sciences 1: 162-165. 
[26] Nikbakht, E., Mohammadi-Nejad, G., Yousefi, K., Farahbakhsh, H. (2010): Evaluation salinity tolerance of safflower (Carthamus tinctorius L.) genotypes at different vegetative growth stages. - International Journal of Agronomy and Plant Production 1: 105-111.

[27] Okcu, G., Kaya, M. D., Atak, M. (2005): Effects of salt and drought stresses on germination and seedling growth of pea (Pisum sativum L.). - Turkish Journal of Agriculture and Forestry 29: 237-242.

[28] Rejili, M., Vadel, A. M., Guetet, A., Neffatti, M. (2007): Effect of $\mathrm{NaCl}$ on the growth and the ionic balance $\mathrm{K}^{+} / \mathrm{Na}^{+}$of two populations of Lotus creticus (L.) (Papilionaceae). South African Journal of Botany 73: 623-631.

[29] Saboora, A., Kiarostami, K. (2006): Salinity $(\mathrm{NaCl})$ tolerance of wheat genotypes at germination and early seedling growth. - Pakistan Journal of Biological Science 9: 20092021.

[30] Shirani Rad, A. H., Abbasian, A. (2011): Evaluation of drought tolerance in winter rapeseed cultivars based on tolerance and sensitivity indices. - Zemdirbyste 98: 41-48.

[31] Siddiqi, E. H., Ashraf, M., Aktram, N. A. (2007): Variation in seed germination and seedling growth in some diverse lines of safflower (Carthamus tinctorius L.) under salt stress. - Pakistan Journal of Botany 39: 1937-1944.

[32] Siddiqi, E. H., Ashraf, M., Hussain, M., Jamil, A. (2009): Assessment of intercultivar variation for salt tolerance in safflower (Carthamus tinctorius L.) using gas exchange characteristics as selection criteria. - Pakistan Journal of Botany 41: 2251-2259.

[33] Zafar, S., Ashraf, M. Y., Niaz, M., Kausar, A., Hussain, J. (2015): Evaluation of wheat genotypes for salinity tolerance using physiological indices as screening tool. - Pakistan Journal of Botany 47: 397-405.

[34] Zeng, L., Shannon, M. C., Grieve, C. M. (2002): Evaluation of salt tolerance in rice genotypes by multiple agronomic parameters. - Euphytica 127: 235-245. 